\title{
Polska produkcja filmowa po roku 2005 w perspektywie badań ilościowych*
}

Od lat 8o. na świecie - a od początku nowego tysiąclecia w Polsce - dynamicznie rozwija się subdyscyplina naukowa określana jako „ekonomia kultury”, „ekonomika kultury” czy - bardziej pragmatycznie - „zarządzanie kulturą”. Rozwój ekonomiki kultury jako nauki, działalność coraz lepiej wykształconych menedżerów kultury czy działalność lobbystyczna i informacyjna instytucji i organizacji kulturalnych pozwala na głębsze zrozumienie procesów kulturowych również w polskim społeczeństwie. Zorganizowany w roku 2009 Kongres Kultury ukazywał rozbieżność języków i poglądów polityków czy elity ekonomicznej oraz twórców kultury i artystów. Jednak właśnie od tego czasu widać stopniowy rozwój tego specyficznego dyskursu interdyscyplinarnego i międzyśrodowiskowego. Terminologia i metodologia ekonomiczna coraz śmielej trafia do języka humanistyki i sztuki, czemu sprzyja i erupcja dziennych, zaocznych czy podyplomowych studiów z tej subdyscypliny, rozwój badań, działalność Narodowego Centrum Kultury - zarówno wydawnicza, przez serię „Kultura się liczy”, jak i poprzez zbieranie czy inicjowanie badań, raportów i artykułów na ten temat. W dyskursie publicznym coraz rzadziej słyszy się popularne jeszcze dekadę temu, a szczególnie u progu kapitalizmu w Polsce w latach 90., hasła o liberalizmie w kulturze, o tym, że - jak mówiono - „kultura powinna się sama wyżywić”. Funkcjonowanie przemysłów kultury, czy też szerzej - przemysłów kreatywnych, w myśli naukowej przedstawiane jest jako proces skomplikowany, wielowarstwowy, $\mathrm{z}$ wielokierunkowymi przepływami dóbr, pieniądza i specjalistów.

Jednocześnie jednak pierwsi naukowcy zmagający się z tą trudną materią stanęli przed wielkim wyzwaniem metodologicznym, szybko zdając sobie sprawę z tego, że na gruncie tej interdyscyplinarnej materii stają się pionierami, tworzącymi pierwsze modele i narzędzia analizy badawczej. Badanie przemysłów kultury czy procesów ekonomicznych zachodzących w kulturze wymaga bowiem stosowania wiedzy przyporządkowanej pozornie rozbieżnym dyscyplinom naukowym.

\footnotetext{
* Autorka jest pracownikiem Wydziału Organizacji Sztuki Filmowej Państwowej Wyższej Szkoły Filmowej, Telewizyjnej i Teatralnej im. Leona Schillera w Łodzi i dedykuje artykuł macierzystej jednostce. Fragmenty artykułu oraz wyniki badań pochodzą z pracy doktorskiej „Kinematografia jako przemysł
}

kultury. Uwarunkowania i tendencje rozwoju branży filmowej w Polsce", praca doktorska napisana pod kierunkiem prof. UKSW Krzysztofa Koehlera, obrona: Uniwersytet Śląski, Wydział Filologiczny, wrzesień 2013. 
Jedna z najsłynniejszych badaczek w tej dziedzinie wiedzy, Ruth Towse, w wydanej także w Polsce książce Ekonomia kultury. Kompendium pisze:

[...] uprawianie jakiejkolwiek nauki stosowanej wymaga znajomości specyficznych cech sektora będącego przedmiotem badań. [...] Nie można uprawiać ekonomii kultury, nie rozumiejąc specyfiki sztuk performatywnych i wizualnych, muzeów i dziedzictwa narodowego, przemysłu medialnego (np. filmowego) czy środków masowego przekazu, a także kreatywności i sposobu kształcenia artystów[1].

Jak dodaje Towse, nie chodzi o to, żeby być dobrze poinformowanym, ale o to, że idee ekonomiczne muszą być odpowiednio zmodyfikowane, aby uwzględniały specyficzne cechy sektorów kulturalnych. $\mathrm{Na}$ tej samej zasadzie nie ma przeszkód, by humanista, znawca sztuki, kina, mediów miał dobrą orientację w prawidłach ekonomicznych rządzących współczesną gospodarką.

Z podobnymi wyzwaniami zetknęli się badacze ekonomiki filmu, nieliczni polscy naukowcy, próbujący zdiagnozować kinematografię poprzez analizę ekonomiczną czy też posługując się narzędziami nauk o zarządzaniu. Ujęcie to nie ma tradycji w polskim dorobku filmoznawczym, poza, w zasadzie, unikatowymi pracami powojennego pioniera ekonomiki filmu Edwarda Zajička[2] i badaczki z Uniwersytetu Śląskiego - Ewy Gębickiej[3].

A przecież kinematografia w dorobku ekonomiki kultury, ale także w licznych opracowaniach eksperckich z ostatniej dekady, traktowana zawsze była jako jeden z najważniejszych przemysłów kultury. W kilkunastu dostępnych klasyfikacjach przemysłów kultury film uwzględniany był zawsze, zwłaszcza że w tym przypadku silnie powiązane znaczeniowo jest pojęcie przemysłu. Kinematografia wymaga dużych nakładów, ale potrafi przynieść także wysokie dochody ze względu na wielość pól eksploatacji; każda produkcja filmu fabularnego tworzy miejsca pracy dla ponad stu osób i powoduje zatrudnienie kilkunastu lub kilkudziesięciu firm. Czynnikiem miękkim, ale istotnym, hamującym rozwój tej wiedzy, jest pewnego rodzaju opór (zwłaszcza środowisk twórczych) wobec traktowania sztuki w kategoriach ekonomii. Świetnie scharakteryzował to jeden z najbardziej cenionych ekonomistów kultury na świecie, David Throsby:

Wielu artystów oburza koncepcja, że ich działania stanowią część przemysłu. Sądzą, że taka perspektywa podkreśla komercyjne aspekty produkcji artystycznej i podporządkowuje czysty impuls twórczy wymogom rynku. [...] Gruboskórny ekonomista szafujący takimi pojęciami, jak: „struktura rynku”, „wskaźnik koncentracji rynku”, „popyt na pracę” oraz „wartość dodana”, faktycznie może im się wydawać nieczuły na bardziej wyrafinowane cele sztuki. A jednak sam fakt, że jednostki i przedsiębiorstwa produkują dobra lub usługi

[1] R. Towse, Ekonomia kultury. Kompendium, przeł. H. Dębowski, K.L. Pogorzelski, Ł.M. Skrok, NCK, Warszawa 2011, s. 34.

[2] E. Zajiček, Poza ekranem. Kinematografia polska w latach 1896-2005, SFP, SF Montevideo, Warszawa 2008.
[3] E. Gębicka, Między państwowym mecenatem a rynkiem. Polska kinematografia po 1989 roku w kontekście transformacji ustrojowej, Wydawnictwo UŚ, Katowice 2006. 
na sprzedaż lub na wymianę, bądź po prostu dla własnej przyjemności, skupia działania artystów wokół pewnych produktów, typów producentów, lokalizacji itp., które można wyodrębnić w kategoriach pojęciowych i określić łącznie mianem „przemysłu” [4].

Z zarysowanymi na wstępie problemami zetknęłam się osobiście, przygotowując w latach 2011-2013 pracę doktorską na Uniwersytecie Kardynała Stefana Wyszyńskiego w Warszawie, zatytułowaną „Kinematografia jako przemysł kultury. Uwarunkowania i tendencje rozwoju branży filmowej w Polsce"[5]. Celem tej pracy było ukazanie współczesnej polskiej kinematografii jako zintegrowanego systemu ekonomiczno-kulturowo-prawnego, przytoczenie rozproszonych danych i pozyskanie własnych, które będą autorskim wkładem w rozwój tej dziedziny wiedzy o filmie. W artykule przedstawiam wyniki tego badania, jednocześnie decydując się na pewien ekshibicjonizm badawczy, czy też, innymi słowy, na swoistą autoetnografię. Krok po kroku opiszę proces dochodzenia do wyników, problemy metodologiczne, decyzje o zastosowaniu określonej metody liczenia czy prezentacji danych czy też stosowania wyjątków. Ponieważ nie miałam narzędzi do tego typu badań, musiałam wypracować je sama. Jako magister filologii polskiej ze specjalnością animacja kultury dysponowałam nader skromną wiedzą o badaniach statystycznych, zwróciłam się więc o pomoc do dra Stanisława Kluzy z Instytutu Statystyki i Demografii Szkoły Głównej Handlowej, który pomógł mi przeprowadzić część analiz. Doszliśmy do wspólnego wniosku, że stosowanie metod liczbowych w badaniu przemysłów kultury wymaga pracy w zespołach interdyscyplinarnych, powinniśmy więc budować kontakty między badaczami $\mathrm{z}$ różnych dziedzin i wspólnie wypracować i przedstawić metodykę badań w kontekście szerszym niż jeden określony przemysł kultury. Wypracowanych przeze mnie narzędzi i metod nie można bowiem traktować jako uniwersalnych do stosowania w całej ekonomii kultury, a jedynie jako odpowiednie do badania określonych procesów zachodzących w sektorze produkcji filmowej.

Wiedziałam ponadto, że pracuję na gruncie słabo udokumentowanym, ale dzięki temu mogłam wypełnić wyraźną lukę w wiedzy o polskim filmie. Serwis branżowy portalfilmowy.pl w katalogu książek filmowych wydanych w roku 2012 doliczył się ponad 240 tytułów: wśród nich pozycje z zakresu ekonomiki filmu zdarzają się rzadko, mniej więcej raz w roku, choć częściej wydawane są na przykład praktyczne podręczniki sztuki filmowej. Działalność publikacyjna i badawcza Polskiego Instytutu Sztuki Filmowej, Krajowej Izby Producentów Audiowizualnych i Stowarzyszenia Filmowców Polskich przyczynia się do uzupełniania tej luki, ale jest to proces rozciągnięty na lata. Przez wiele lat zbierałam rozproszone dane na temat produkcji, dystrybucji filmowej, kultury filmowej i kin w Polsce. Uznałam, że siedem lat po

[4] D. Throsby, Ekonomia i kultura, przeł. O. Siara, NCK, Warszawa 2010, s. 102.
[5] A. Wróblewska, „Kinematografia jako przemysł kultury. Uwarunkowania i tendencje...” 
wprowadzeniu w życie nowego prawa filmowego nadszedł czas na pierwszy zwarty tekst naukowy na temat nowej polskiej kinematografii rozumianej jako przemysł kultury.

Dane na temat branży filmowej w Polsce były niepełne, bardzo rozproszone, niepublikowane. Dotyczyło to zwłaszcza danych dotyczących produkcji. Dane na temat dystrybucji kinowej były zbierane wiele lat i pochodzą z firmy Boxoffice.pl, która monitoruje rynek kinowy. Dane dotyczące rynku kin udostępnił Polski Instytut Sztuki Filmowej, który zbierał informacje o kinach wielosalowych i tradycyjnych; informacje te uzupełnią dane na temat Sieci Kin Studyjnych i Lokalnych z Filmoteki Narodowej. Dlatego badacz, który zdecyduje się na analizę rynku kin i dystrybucji filmowej, ma dobry wyjściowy materiał badawczy.

Najtrudniejszą - a jednocześnie kluczową - częścią pracy okazało się przedstawienie produkcji za pomocą danych ilościowych. Od czasu wprowadzenia ustawy o kinematografii nie zdecydowano się na policzenie wynikowej wartości rynku filmów z dofinansowaniem publicznym, nie dysponowałam także pełnymi listami polskich filmów. Oszczędne dane o produkcji podawane do tej pory przez PISF opierały się na treściach zawartych we wnioskach składanych w Instytucie, które są tylko założeniem kształtu budżetowego i produkcyjnego filmu. Zdecydowałam się więc sięgnąć do archiwów PISF, w tym przede wszystkim do raportów producentów filmów fabularnych. Dzięki nim można przedstawić najważniejsze źródła finansowania polskiego filmu. Analiza statystyk pozwoliła na sformułowanie wniosków i przedstawienie pierwszego kompletnego obrazu polskiego przemysłu filmowego po roku 2005.

Poważnym ograniczeniem badawczym okazał się także fakt, że dane o filmach, które powstały bez udziału PISF, są w zasadzie niemożliwe do zebrania. Telewizje i pozostali producenci nie chcą ujawniać wysokości budżetów swoich filmów ani udziału partnerów. Bardzo często zdarza się, że firma wymieniona w napisach już nie istnieje, a prawa przejął inny podmiot, który nie widzi potrzeby ujawniania takich danych. W związku $\mathrm{z}$ tym ograniczenie się tylko do produkcji realizowanych $z$ udziałem PISF powoduje, że otrzymujemy zbiór wiarygodny, jasno określony, choć ograniczony.

Film niejedno ma imię, czyli roczna produkcja w liczbach
Ustawa o kinematografii wpłynęła na cały system polskiej kinematografii, ale w największym stopniu jednak na segment produkcji filmowej. Zmiany widoczne są zarówno w liczbie filmów, jak i w sposobie działania producentów, a także w rozkładzie planów zdjęciowych, w liczbie i formie instytucji filmowych oraz w zestawieniu działających studiów produkcyjnych.

W roku 2006, w pierwszym roku swojej działalności, Polski Instytut Sztuki Filmowej podał liczbę filmów fabularnych produkowanych w Polsce od roku 2000 (niestety, nie podał jednocześnie liczby filmów dokumentalnych i animowanych). Wyniki te należy jednak traktować 
z dystansem, w zależności od tego, jaką definicję filmu przyjmiemy i czy używając określenia „pełnometrażowy”, będziemy mieć na myśli podział jedynie na filmy krótkometrażowe i pełnometrażowe, czy uwzględnimy kategorię średniego metrażu. Definicje te znalazły się w ustawie o kinematografii z roku 2005 lub powiązanych z nią „Zarządzeniach” i „Programach Operacyjnych PISF”. Ustawa precyzuje także pojęcie filmu, przede wszystkim jako specyficznego dobra kultury istniejącego w konkretnym systemie i sposobie rozpowszechniania. Filmem jest:

[...] utwór dowolnej długości, w tym utwór dokumentalny lub animowany, złożony z serii następujących po sobie obrazów z dźwiękiem lub bez dźwię$\mathrm{ku}$, utrwalonych na jakimkolwiek nośniku umożliwiającym wielokrotne odtwarzanie, wywołujących wrażenie ruchu i składających się na oryginalną całość, wyrażającą akcję (treść) w indywidualnej formie, a ponadto, $\mathrm{z}$ wyjątkiem utworów dokumentalnych i animowanych, przeznaczony do wyświetlania w kinie jako pierwszym polu eksploatacji w rozumieniu przepisów o prawie autorskim i prawach pokrewnych[6].

Zapis o indywidualnej formie i oryginalnej całości eliminuje z obszaru filmu odcinki serii dokumentalnej, rejestracje wydarzeń kulturalnych czy proste reportaże, a zapis o kinie jako pierwszym polu eksploatacji eliminuje reklamy w postaci minifabuł. Jak się jednak okazuje, nawet ustawowy zapis definicji nie rozwiązał sprawy jednoznacznej klasyfikacji filmów.

Tabela 1. Pełnometrażowe filmy polskie $2000-2006 \mathrm{w}$ liczbach

\begin{tabular}{lll}
\hline Rok & $\begin{array}{l}\text { Pełnometrażowe filmy polskie } \\
\text { wg PISF }\end{array}$ & $\begin{array}{l}\text { Pełnometrażowe filmy polskie } \\
\text { wg MKiDN }\end{array}$ \\
\hline 2000 & 28 & 23 \\
2001 & 31 & 19 \\
2002 & 28 & 17 \\
2003 & 21 & 21 \\
2004 & 27 & 20 \\
2005 & 30 & 29 \\
2006 & 36 & - \\
\hline
\end{tabular}

Źródło: PISF, MKiDN.

Uderzają różnice w obu zestawieniach. Zapaść z przełomu XX i XXI wieku najwyraźniej odcisnęła się na poziomie ówczesnych edycji Festiwalu Filmów Fabularnych w Gdyni, probierzu kondycji polskiego kina. Festiwal nie stosował wówczas selekcji. Liczba filmów wyprodukowanych z przeznaczeniem do kina była tak niewielka, że posiłkowano się filmami z nowo objawionego nurtu kina niezależnego, offowego, oraz filmami telewizyjnymi. Na początku XXI wieku TVP wróciła bowiem do produkcji godzinnych filmów telewizyjnych w dwóch programach pro-

[6] Ustawa z dnia 30 czerwca 2005 r. o kinematografii

(Dz.U. z 2005 r. Nr 132 poz. 1111, art. 4.1). 
dukcyjnych: przeznaczonym dla debiutantów znakomitym cyklu „Pokolenie 200o” oraz w popularnej, mainstreamowej serii „Święta polskie”.

Podczas mojej pracy w Stowarzyszeniu Filmowców Polskich i Polskim Instytucie Sztuki Filmowej zapoznałam się z praktyką tworzenia rocznych list filmów. Oprócz oficjalnej produkcji kinowej, wspartej z budżetu państwa albo - bardzo rzadko - nie dotowanej, do list tych włączano filmy niezależne, które trafiły do dystrybucji, filmy niezależne i telewizyjne, które reprezentowały Polskę na ważnych festiwalach filmów fabularnych na świecie, lub filmy, które weszły do Konkursu Głównego Festiwalu Polskich Filmów Fabularnych w Gdyni, a nawet do programu festiwalu debiutów „Młodzi i Film” w Koszalinie. Tłumaczy to rozbieżności w listach tworzonych przez resort kultury i Polski Instytut Sztuki Filmowej, powstały w połowie roku 2005.

Jak widać, praca dokumentacyjna resortu kultury kończy się w momencie powołania urzędu właściwego do spraw kinematografii. Czym tłumaczyć ogromną liczbę 36 filmów w 2006 roku? Odpowiedzi jest na to kilka. Większość tej produkcji powstała jeszcze według starego systemu, PISF przejął stare zobowiązania Agencji Produkcji Filmowej. Kilka tańszych filmów powstało z dotacji udzielonej przez PISF. To jednak nie tłumaczy tak wysokiej liczby tytułów. Otóż podawanie takiej liczby ma przede wszystkim cel propagandowy, należy założyć, że Instytut, na początku swojej działalności atakowany przez przeciwników ustawy, przyjął najszersze możliwe kryterium klasyfikacyjne.

Polski Instytut Sztuki Filmowej ogłosił pierwszą edycję Programów Operacyjnych w styczniu 2006 roku. Oznacza to, że o realnych efektach pracy Instytutu można mówić w roku 2007, do tego czasu bowiem filmy powstawały głównie na podstawie dawnych zobowiązań Agencji Produkcji Filmowej. Od razu należy zaznaczyć, że filmy dofinansowane przez Polski Instytut Sztuki Filmowej nie stanowią pełnego katalogu polskiej produkcji filmowej, ale jego znaczącą część. Podczas ustalania liczby filmów okazało się jednak, że każdy z trzech rodzajów filmowych ma własną specyfikę i każdy wymaga osobnego systemu liczenia. W dziedzinie filmu animowanego liczby filmów wyprodukowanych w latach 2006-2011 prezentują się następująco:

Tabela 2. Liczba polskich filmów animowanych wyprodukowanych w latach 2006-2011

\begin{tabular}{lc}
\hline Rok & Liczba filmów \\
\hline 2006 & 22 \\
2007 & 20 \\
2008 & 31 \\
2009 & 30 \\
2010 & 37 \\
2011 & 35 \\
\hline
\end{tabular}

Źródło: opracowanie własne. 
Przygotowując powyższe zestawienie wzięłam pod uwagę czynniki, o których pisałam powyżej: dofinansowanie przez PISF i inne instytucje publiczne, obecność na festiwalach, profesjonalizm twórców. W przypadku filmu animowanego szczególną trudność w zakwalifikowaniu utworu do nurtu produkcji profesjonalnej stanowi fakt, że wielu znakomitych twórców, jak np. Piotr Kamler, przygotowuje swoje filmy poza systemem, we własnych pracowniach; ponadto animacja jest słabo opisana, filmografie niepełne, dlatego dane te należy traktować jako przybliżone. Należy zaznaczyć, że filmy pełnometrażowe stanowią pojedyncze pozycje $\mathrm{z}$ tej listy, co związane jest $\mathrm{z}$ dużymi kosztami produkcji animacji. Osobnym problemem są granice gatunku - czasem trudno określić, czy dane dzieło łączyć z domeną plastycznych sztuk wizualnych, czy z filmową animacją, tym bardziej że są twórcy, którzy płynnie przechodzą od visual arts do animowanego filmu eksperymentalnego.

Również w przypadku filmu dokumentalnego trudność stanowią zatarte często granice gatunku. Bardzo często twórcy reportaży dążą do uznania ich dzieł za filmy dokumentalne. Dlatego wykorzystałam wiedzę i doświadczenie Krakowskiej Fundacji Filmowej, instytucji monitorującej rynek i zajmującej się promocją polskiego dokumentu.

Tabela 3. Liczba polskich filmów dokumentalnych w latach 2007-2011

\begin{tabular}{lcccccc}
\hline Rok & Krótki metraż & Średni metraż & Długi metraż & Razem & W tym koprodukcje & Niejednoznaczne \\
\hline 2007 & 65 & 53 & 7 & 125 & 10 & $30-35$ \\
2008 & 66 & 71 & 17 & 154 & 10 & $18-20$ \\
2009 & 71 & 79 & 10 & 160 & 12 & 35 \\
2010 & 61 & 68 & 18 & 147 & 22 & 22 \\
2011 & 75 & 53 & 11 & 139 & 16 & 15 \\
\hline
\end{tabular}

Źródło: Krakowska Fundacja Filmowa.

Filmy dokumentalne stanowią najliczniejszą część polskiej produkcji filmowej, najtrudniej je także zliczyć i zakwalifikować. Decyzja, czy film obejrzany w telewizji, np. TVN24, jest filmem czy reportażem, to często kwestia decyzji eksperckiej. Krakowska Fundacja Filmowa co roku otrzymuje dziesiątki zgłoszeń do konkursu Krakowskiego Festiwalu Filmowego. Oprócz filmów dokumentalnych w tradycyjnym znaczeniu tego słowa, przysyłane są zgłoszenia reportaży telewizyjnych, a nawet bardziej udanych odcinków serii dokumentalnej. Stąd tak wysoka liczba produkcji określonych jako niejednoznaczne. Dlatego też dane te trzeba traktować jako orientacyjną wielkość polskiej produkcji dokumentalnej w badanym okresie.

Dynamika liczbowa produkcji filmów fabularnych w interesującym mnie okresie po wykonaniu badań własnych wygląda jak $\mathrm{w}$ poniższym zestawieniu. 
Tabela 4. Liczba pełnometrażowych i średniometrażowych (od 50 minut) filmów fabularnych w latach 2006-2011

\begin{tabular}{lccc}
\hline Rok & $\begin{array}{l}\text { Liczba } \\
\text { filmów }\end{array}$ & $\begin{array}{l}\text { W tym dofinansowane } \\
\text { przez PISF }\end{array}$ & $\begin{array}{l}\text { Wśród dofinansowa- } \\
\text { nych: pożyczki }\end{array}$ \\
\hline 2006 & 33 & $\begin{array}{l}\text { 20 (głównie dawne } \\
\text { decyzje APF) }\end{array}$ & - \\
2007 & 28 & 21 & - \\
2008 & 33 & 27 & 1 \\
2009 & 47 & 37 & 1 \\
2010 & 54 & 42 & 2 \\
2011 & 43 & 32 & 4 \\
\hline
\end{tabular}

Źródło: opracowanie własne.

Podobnie jak w przypadku filmów dokumentalnych i fabularnych, zestawienie to wymaga obszernego komentarza. Prace nad zestawieniem fabuł prowadziłam przez kilka lat, na potrzeby publikacji w takich mediach Stowarzyszenia Filmowców Polskich, jak „Magazyn Filmowy SFP” czy bazafilmowa.pl. Jednakże po kilku latach należy tę listę zweryfikować. Wynika to z faktu, że niezwykle trudno jest zdefiniować, czym jest profesjonalny film fabularny. Do takiego zestawienia należy zakwalifikować wszystkie filmy dofinansowane przez PISF oraz filmy wyprodukowane przez TVP i TVN, o ile przekraczają one $50 \mathrm{mi}$ nut (w zasadzie film pełnometrażowy trwa od 60 minut, ale są sytuacje, kiedy za pełen metraż można uznać film krótszy, głównie ze względu na przeznaczenie emisyjne). Dołączyłam do listy profesjonalne filmy komercyjne, np. komedie romantyczne, które rzadko korzystają ze wsparcia publicznego, oraz coraz liczniejsze koprodukcje międzynarodowe. Zdarzają się także utwory niskobudżetowe, np. debiutanckie filmy, które realizują profesjonalni producenci (np. Ego Krzysztofa Jankowskiego, Łódzkie Centrum Filmowe). Problem natomiast leży w kwalifikacji filmów z nurtu tzw. offu, które w jakiś sposób wybiły się ze swojego niezależnego statusu.

W Polsce od około roku 2000 kino offowe rozwija się równolegle do tzw. kina profesjonalnego. Bardzo często tworzą je twórcy profesjonalni, ale poza regularnym systemem wsparcia. Rezultaty artystyczne tych poszukiwań twórczych są czasami bardzo interesujące. Zdarza się, że filmy z założenia offowe przebijają się do widowni - np. otrzymując ważne nagrody na najważniejszych festiwalach, trafiając do studyjnej dystrybucji kinowej czy telewizyjnej lub na VOD. Są to tradycyjne, uznawane dawniej przez resort kultury kryteria profesjonalnej produkcji, jednakże każdy przypadek należy rozpatrywać indywidualnie. Dlatego i w przypadku filmów fabularnych liczba tytułów może być traktowana wyłącznie orientacyjnie.

Analiza tytułów już w pierwszym okresie obowiązywania nowego prawa pokazuje, że od roku 2006 filmy ujęte na listach polskich 
filmów profesjonalnych są nimi w istocie. Filmy offowe, telewizyjne, stanowią w nich widoczną mniejszość. Wzrasta liczba polskich filmów, od kilku lat stabilizuje się na poziomie 40. Należy wziąć pod uwagę, że wśród zliczonych tytułów znajdują się także koprodukcje, zarówno mniejszościowe, jak i większościowe, które na etapie tak daleko idących uproszczeń i podsumowań mogą ten ilościowy obraz zakłócać. Dlatego systemowi liczenia koprodukcji należy się osobna eksplikacja.

Powstanie PISF nie było jedynym czynnikiem, który spowodował gwałtowny rozwój koprodukcji filmowych. Polscy producenci zaczęli korzystać z programów europejskich, jak Media czy Eurimages, wyjeżdżali na festiwale i targi, zapoznali się ze sztuką pitchingu. Szkolenia dla producentów z zakresu promocji i dystrybucji międzynarodowej od kilku lat organizowane są również w Polsce - przez organizacje filmowe, PISF i Mediadesk Polska.

Od roku 2006 statystyka koprodukcji w polskiej kinematografii wygląda następująco:

Tabela 5. Koprodukcje międzynarodowe z udziałem Polski w latach 2006-2011

\begin{tabular}{lcccc}
\hline Koprodukcje & Liczba & Mniejszościowe z PISF & Większościowe z PISF & Bez udziału PISF \\
\hline 2006 & 4 & 3 & 3 & 1 \\
2007 & 7 & 5 & 3 & 2 \\
2008 & 10 & 7 & 5 & 2 \\
2009 & 14 & 9 & 3 & 1 \\
2010 & 13 & 7 & 4 & 0 \\
2011 & 11 & & & \\
\hline
\end{tabular}

Źródło: opracowanie własne.

W języku produkcji filmowej koprodukcje dzielą się na większościowe i mniejszościowe. Rozróżnienie to stosuje się wobec filmów, które mają dominujący polski udział w budżecie filmu. Koprodukcje mniejszościowe to takie, w których Polska ma udział mniejszościowy, najczęściej na poziomie 10-20 proc. Zastosowałam jeden wyjątek. Jako większościowe potraktowałam także te produkcje, których budżet nie pochodził wprawdzie w ponad 50 proc. z polskich źródeł, stanowią one jednak dokonania polskich twórców i należy je określić jako dorobek polskiej kinematografii - jak Cztery noce z Annq (2008) Jerzego Skolimowskiego, Sponsoring (2011) Małgorzaty Szumowskiej i W ciemności (2011) Agnieszki Holland.

Wydaje się, że w ciągu kilku lat tendencje w profesjonalnej produkcji filmów fabularnych w Polsce zdążyły się ustabilizować. Polska produkowała w okresie 2009-2011, a więc tym najbardziej reprezentatywnym, od 43 do 54 filmów rocznie, wliczając w to od 7 do 9 koprodukcji mniejszościowych, których nie można uznać za filmy polskie, a jedynie filmy z polskim udziałem. W liczbie produkowanych w latach 2007-2011 filmów od 7 do 14 rocznie to koprodukcje, $z$ czego 3 do 5 to 
koprodukcje będące filmami polskimi. Zdecydowana większość filmów powstaje z udziałem Polskiego Instytutu Sztuki Filmowej - od 74 do 81 proc. produkcji. Poza systemem publicznego wsparcia powstają filmy niezależne, które dość regularnie zasilają oficjalny nurt polskiej kinematografii, a także telewizyjne filmy produkowane przez TVN i większość filmów komercyjnych - komedie obyczajowe i romantyczne.

Jak widać z przedstawionych liczb, nie ma uniwersalnej metody stwarzania oficjalnego katalogu rocznej produkcji. Rozbieżności są widoczne nawet pomiędzy poszczególnymi rodzajami filmów. Należy wziąć pod uwagę, że w światowej, a co za tym idzie - także polskiej, kinematografii pojawiają się formy hybrydyczne, mieszane. Rozwój kina z pogranicza gatunków, jak mocumentary czy animadoc, nie ułatwia zdefiniowania jasnych kryteriów klasyfikacyjnych. Każda lista oficjalnej produkcji będzie więc miała charakter w pewnym stopniu autorski.

\section{Badania ilościowe budżetów filmów i udziałów poszcze- gólnych podmiotów}

Obszar badawczy. W rozdziale tym zaprezentuję dane pochodzące z dokumentów źródłowych Polskiego Instytutu Sztuki Filmowej, zebrane przeze mnie w czasie kwerendy archiwalnej w zbiorach Instytutu. Pochodzą z raportów końcowych, które producenci składają do urzędu po zakończeniu realizacji dotowanego filmu. Jest to pierwsze tego typu zestawienie, jako że do tej pory prób oszacowania średniego budżetu czy udziału środków publicznych dokonywano na podstawie wniosków, a nie rozliczeń. Dane, które uzyskałam, są w największym stopniu zgodne ze stanem faktycznym, a przynajmniej z oficjalnym rozliczeniem filmu. Oczywiście nie można wykluczyć sytuacji, w której producent stosuje tzw. kreatywną księgowość lub wręcz podaje fałszywe informacje. Od kilku lat PISF wprowadził obowiązek audytu produkcji dofinansowanych ze środków publicznych, który prowadzą wyznaczone niezależne biura audytorskie. Czasem zresztą nie musimy mieć do czynienia z kreatywną księgowością lub nieuczciwością, tylko z klasyfikacją wydatków w sposób najbardziej wygodny dla producenta. Nawet jednak biorąc pod uwagę te zastrzeżenia, posłużenie się raportami złożonymi do urzędu wydaje się metodą najbardziej pragmatyczną i najbliższą rzeczywistości.

Zdecydowałam się ograniczyć zakres badań do filmów dofinansowanych przez Instytut. Stanowią one około 75 proc. produkcji fabularnej w roku. Do informacji o budżetach filmów niedofinansowanych ze źródeł publicznych dostęp jest utrudniony. TVN nie chce podawać budżetów swoich produkcji, a część firm, które wyprodukowały filmy, zwłaszcza kilka lat temu, już nie istnieje. Poza tym trudno zweryfikować wiarygodność takich danych.

Średni budżet polskiego filmu. Badając średni budżet polskiego filmu z lat 2007-2011, podjęłam decyzję o wyeliminowaniu $\mathrm{z}$ większości zestawień koprodukcji mniejszościowych, których nie można uznać za filmy polskie, a do których Polska dokłada się jako partner, a nie producent główny. Wynika to $\mathrm{z}$ faktu, że uwzględnienie w badaniach 
średniej tych koprodukcji znacząco podwyższyłoby wynik. Na liście koprodukcji znajdują się filmy o budżetach nieodbiegających od przeciętnej polskiej średniej, są też jednak takie, których budżet kilkakrotnie przewyższa polską praktykę. Poniższa tabela podaje wyniki badań budżetów filmowych:

Tabela 6. Średni budżet polskiego filmu fabularnego w latach 2007-2011 [PLN]

\begin{tabular}{lllll}
\hline Rok & $\begin{array}{l}\text { Średni budżet filmu } \\
\text { z uwzględnieniem } \\
\text { wszystkich danych }\end{array}$ & Średnia z pięciu lat & $\begin{array}{l}\text { Średni budżet filmu po odjęciu } \\
\text { filmów wysokobudżetowych } \\
\text { (ujęcie autorskie) }\end{array}$ & Średnia z pięciu lat \\
\hline 2007 & 4283417,00 & & 3445295,00 & \\
2008 & 3840302,00 & 3123494,00 & 3636914,00 \\
2009 & 4479655,00 & 4636707,20 & 3811915,00 & \\
2010 & 4053526,00 & & 3416933,00 & \\
2011 & 6526636,00 & & 4385820,00 & \\
\hline
\end{tabular}

Źródło: opracowanie własne.

Na czym polega różnica między danymi z lewej części tabeli a danymi z części prawej? Czym tłumaczyć, dlaczego w tym samym roku średni budżet filmu może być liczony inaczej? Różnica między obu częściami tabeli polega na tym, że w przypadku tej drugiej wyłączyłam filmy najdroższe, których produkuje się nie więcej niż 2-3 rocznie, filmy kostiumowe czy kosztowne koprodukcje, takie jak m.in. 1920. Bitwa Warszawska (ponad $25 \mathrm{mln} \mathrm{zł}$ ), Sponsoring (ponad $14 \mathrm{mln} \mathrm{zł}$ ), W ciemności (ponad 20 mln zł), Essential Killing (ok. 13 mln zł), Katyń (ok. $16 \mathrm{mln} \mathrm{zł),} \mathrm{oraz} \mathrm{kilka} \mathrm{współczesnych} \mathrm{z} \mathrm{dużą} \mathrm{inscenizacją} \mathrm{i} \mathrm{efek-}$ tami specjalnymi. Nie zdecydowałam się na wyeliminowanie $\mathrm{z}$ tych obliczeń filmów najtańszych. Praktyka pokazuje bowiem, że nie ma więcej bardzo drogich filmów polskich poza tymi, które widnieją w statystykach PISF, natomiast wśród filmów niezależnych jest co najmniej kilka rocznie o niskim lub wręcz symbolicznym budżecie. Jest więc to ujęcie autorskie, podyktowane doświadczeniem i praktyką, nie zaś metodą badań statystycznych.

Nawet pobieżna obserwacja danych prowadzi do dwóch spostrzeżeń. Budżety filmów na przestrzeni 5 lat wzrosły o ponad 20 proc., biorąc pod uwagę ujęcie „autorskie”. Zwraca uwagę nieprzystawalność danych $\mathrm{z}$ roku 2011 do średnich $\mathrm{z}$ lat poprzednich, zwłaszcza gdy analizuje się liczby bezwzględne. Wynika to z faktu, że w roku 2011 w Polsce wyprodukowano trzy drogie filmy: $W$ ciemności, Sponsoring i 1920. Bitwa Warszawska. Przy ograniczonej skali produkcji i ograniczonych środkach na dotacje, musiało to zwiększyć średni budżet, ale zapewne wpłynęło także na obniżenie liczby filmów w produkcji. Produkcja kosztownego filmu wojennego albo trójstronnej koprodukcji z wielką gwiazdą to zawsze wyjątkowe wydarzenie w polskiej kinematografii, nie może być więc traktowane jako standard, ale jako znacznie większy wysiłek finansowy i organizacyjny. Ten właśnie 
przypadek zdecydował o tym, że zaproponowałam ujęcie własne badań średniego budżetu filmu. Realny średni budżet mieści się więc między tymi dwoma szeregami wartości i wynosi mniej więcej $4 \mathrm{mln}$ zł, czyli $1 \mathrm{mln}$ euro.

Analiza budżetów filmów podanych w tabeli 6 prowadzi do wniosku, że wynik zbliżony jest do najczęściej występujących w ostatnich latach. Poniższa tabela pokazuje, ile powstaje w Polsce filmów nisko-, średnio- i wysokobudżetowych z dofinansowaniem publicznym.

Tabela 7. Podział rocznej produkcji ze względu na budżet

\begin{tabular}{lrcccc}
\hline Budżet filmu [PLN] & 2007 & 2008 & 2009 & 2010 & 2011 \\
\hline Do 4 mln & 14 & 13 & 12 & 18 & 7 \\
$4-8 \mathrm{mln}$ & 3 & 8 & 15 & 13 & 14 \\
Powyżej $8 \mathrm{mln}$ & 1 & 1 & 2 & 1 & 4 \\
\hline
\end{tabular}

Źródło: opracowanie własne.

Nie mam dostępu do informacji o budżetach filmów realizowanych poza systemem publicznego wsparcia. Na podstawie własnego szacunku i wiedzy eksperckiej zwiększyłabym o kilka rocznie liczbę filmów $\mathrm{z}$ budżetem do $4 \mathrm{mln}$ zł (filmy niezależne) i filmów $\mathrm{z}$ budżetem w przedziale $4^{-8} \mathrm{mln}$ zł, w tych granicach zawierają się bowiem koszty produkcji filmów komediowych i sensacyjnych realizowanych poza oficjalnym systemem finansowania. Do grupy filmów o budżecie do 4 mln zł należą także produkcje TVN z cyklu „Proste historie” (według oświadczeń kierowników produkcji).

Zwiększoną liczbę filmów o dużych budżetach w roku 2011 traktowałabym, przy tak ograniczonym obszarze badawczym, na razie jako wypadkową wielu zdarzeń. Produkcja filmu, zwłaszcza wysokobudżetowego, trwa kilka lat. Data copyrightu (rok ukończenia filmu) jest więc wynikiem licznych czynników. Być może po roku 2013 należałoby sprawdzić, czy liczba superprodukcji utrzymała się na podobnym poziomie, na razie sformułuję tezę, że produkcja filmów wysokobudżetowych w Polsce utrzymuje się na poziomie dwóch rocznie.

Zwraca uwagę inna tendencja, w moim przekonaniu korzystna dla profesjonalnej kinematografii. Wzmacnia się nurt mainstreamowy. Powstaje coraz więcej filmów wysokobudżetowych. Przekłada się to na oczekiwania widowni, która, poza widzami najbardziej wyrobionymi, żąda kina dobrze zrealizowanego, o wysokim standardzie technicznym, dobrej i starannej inscenizacji.

Udział środków publicznych w rocznej produkcji filmów fabularnych. Jedną z najważniejszych informacji z punktu widzenia funkcjonowania systemu kinematografii jest ta o udziale środków publicznych w produkcji filmów fabularnych. Pokazuje ona w liczbach, jakie czynniki, instytucje i uwarunkowania powodują wzrost lub zmniejszenie skali produkcji. 
Najistotniejszym czynnikiem jest udział PISF w sumie budżetów polskich filmów fabularnych. I tym razem zdecydowałam się ograniczyć do zestawienia zawierającego filmy polskie i koprodukcje polskie większościowe, także po to, by nie fałszować ogólnego obrazu. Po przebadaniu 126 raportów końcowych filmów udział PISF w ogólnym budżecie zrealizowanych filmów przedstawia się następująco:

Tabela 8. Udział PISF w rocznym budżecie produkcji filmów w Polsce w latach 2007-2011

\begin{tabular}{llll}
\hline Rok & $\begin{array}{l}\text { Budżety łącznie } \\
{[\text { PLN] }}\end{array}$ & $\begin{array}{l}\text { Wkład PISF } \\
{[\text { PLN] }}\end{array}$ & $\begin{array}{l}\text { Wkład PISF } \\
{[\%]}\end{array}$ \\
\hline 2007 & 69125444,54 & 28974281,14 & 41,91 \\
2008 & 89951765,31 & 35217491,71 & 39,15 \\
2009 & 129910013,74 & 53534049,88 & 41,20 \\
2010 & 129455021,87 & 63008885,52 & 48,67 \\
2011 & 163165919,34 & 70215277,00 & 43,03 \\
\hline
\end{tabular}

Źródło: opracowanie własne.

Zwraca uwagę rok 2010, podobnie zresztą jak w analizach filmów średniobudżetowych. W latach 2009-2010 TVP wycofywała się z produkcji filmów. Widać, że utrata tak ważnego źródła finansowania filmów fabularnych jednocześnie zubożyła produkcję, ale także - musiało zwiększyć się zaangażowanie PISF, aby utrzymać wcześniejszą wielkość rocznej produkcji.

Od roku 2007 działają w Polsce Regionalne Fundusze Filmowe. Przez pierwsze lata udział pieniądza samorządowego wzrastał, by ustabilizować się na poziomie ok. $4 \mathrm{mln}$ zł rocznie przeznaczanych na wspieranie fabuł. Tabela udziału RFF-ów oraz pozostałych środków Jednostek Samorządu Terytorialnego, a także innych źródeł publicznych, wygląda następująco:

Tabela 9. Liczba filmów dofinansowanych przez Jednostki Samorządu Terytorialnego, Regionalne Fundusze Filmowe i inne instytucje publiczne w latach 2007-2011 oraz ich udział w ogólnych nakładach na kinematografię w tym okresie

\begin{tabular}{cccc}
\hline $\begin{array}{l}\text { Liczba filmów dofinanso- } \\
\text { wanych z JST 2007-2011 }\end{array}$ & $\begin{array}{l}\text { Odsetek udziału JST } \\
\text { w ogólnych nakładach na } \\
\text { kinematografię }\end{array}$ & $\begin{array}{l}\text { Liczba filmów dofinanso- } \\
\text { wanych z innych środków } \\
\text { publicznych 2007-2011 }\end{array}$ & $\begin{array}{l}\text { Odsetek udziału innych } \\
\text { sodków publicznych } \\
\text { wa kinemch nakładach } \\
\text { natię }\end{array}$ \\
\hline 32 & 2,47 & 6 & 0,76 \\
\hline
\end{tabular}

Źródło: opracowanie własne.

Udział ten jest zaskakująco niski. Nie należy go jednak lekceważyć, pamiętając, że na budżet filmów składają się także aporty rzeczowe, podczas gdy dofinansowanie $z$ regionów zawsze ma charakter finansowy. Stanowi języczek u wagi i czasem decyduje o domknięciu budżetu filmu. 
Zaangażowanie PISF w produkcję filmów wynosi od 39 do 49 procent w skali pięciu lat. To ogromnie duży udział, zważywszy, że poza systemem powstaje $20^{-2} 2$ procent filmów profesjonalnych rocznie. Oznacza to, że system produkcji filmów właściwie zależny jest od PISF. Bez wsparcia Instytutu powstać mogą albo filmy offowe i niskobudżetowe debiuty, albo filmy komercyjne, jak komedie realizowane dla szerokiej widowni. Dofinansowania z innych źródeł publicznych mieszczą się w granicach błędu statystycznego. Poza Regionalnymi Funduszami Filmowymi czasami do produkcji dołożyć się mogą takie instytucje, jak np. MKiDN, Narodowe Centrum Kultury, a w dalszej perspektywie także Narodowy Instytut Audiowizualny, który raczej będzie zainteresowany wsparciem gatunków pozafabularnych.

Zakończenie.

Pierwsza próba oszacowania wartości rynku produkcji filmowej
Uzyskanie danych z raportów producenckich stało się punktem wyjścia do badań statystycznych, wykonanych za pomocą arkuszy excelowych przy wsparciu dra Stanisława Kluzy. Aby uzyskać wiarygodne wyniki, filmy podzielono na kilka grup danych i oznakowano kodami, na przykład:

kolor żółty (kod: zo) - filmy polskie dofinansowane przez PISF, kolor szary (kod: sz) - koprodukcje większościowe dofinansowane przez PISF,

kolor różowy (kod: ro) - koprodukcje mniejszościowe, kolor niebieski (kod: nb) - filmy z pożyczką PISF,

kolor zielony (kod: zi) - filmy niedofinansowane przez PISF, brak danych o budżetach.

Dzięki zastosowaniu kodów stało się możliwe zestawianie danych w dowolny sposób i obserwowanie różnic pomiędzy poszczególnymi grupami filmów.

W całościowych liczbowych badaniach sektorowych zastosowano podział filmów na następujące grupy: filmy polskie dofinansowane przez PISF, koprodukcje mniejszościowe i większościowe dofinansowane przez PISF, pożyczki. Poniższe tabele ilustrują, jak rozkładały się wydatki PISF na produkcję filmów fabularnych w latach 2007-2011.

Tabela 10. Odsetek całości dotacji PISF w poszczególnych latach 2007-2011 przeznaczony na produkcję filmów fabularnych (wliczając koprodukcje mniejszościowe)

\begin{tabular}{lc}
\hline Rok & $\begin{array}{l}\text { Odsetek całości dotacji przeznaczony przez PISF } \\
\text { na produkcję filmów fabularnych }\end{array}$ \\
\hline 2007 & 11,22 \\
2008 & 14,20 \\
2009 & 22,63 \\
2010 & 24,61 \\
2011 & 27,35 \\
\hline
\end{tabular}

Źródło: opracowanie własne. 
Tabela ta pokazuje, w jaki sposób rozkładały się środki, które PISF przeznaczał na produkcję fabuł w latach 2007-2011. Jej wyniki są bardzo znaczące i należy zinterpretować je jako pozytywne dla sytuacji polskiej branży filmowej. W roku 2011 Instytut przeznaczył na wsparcie kinematografii około 250 proc. środków więcej niż na początku swojej działalności. To pozytywne zjawisko, oznacza bowiem, że na produkcję filmów fabularnych przeznacza się znacząco większe i narastające kwoty. Wynika to z faktu, że pieniądze w Instytucie kumulują się. Film, dofinansowany decyzją z roku 2008, ostatecznie może mieć rok produkcji 2011. To przyrastanie pieniądza pokazuje, że ustawa o kinematografii stworzyła system samonapędzający się, gwarantujący stabilność w niestabilnym otoczeniu. Praktyka ostatnich lat, ale i dane liczbowe pokazują, że PISF jest jedynym stabilnym źródłem finansowania. Polityka TVP jest zmienna, dopiero od dwóch lat nadawca publiczny stopniowo wraca do inwestowania w polską produkcję filmową. Trudno przewidzieć, na ile jest to tendencja trwała.

Podobnie jest $\mathrm{z}$ innymi kluczowymi inwestorami na rynku. Canal+ po kilkuletniej stagnacji znowu zaczął koprodukować filmy, ale fuzja $\mathrm{z}$ platformą $\mathrm{N}$ spowodowała spowolnienie tych procesów i brak nowych inwestycji. W ostatnich latach znaczącym inwestorem w branżę filmową była Telekomunikacja Polska występująca pod marką Orange. Wydaje się, że można w tej chwili również zaobserwować przystopowanie tych zadań, być może pod wpływem spadku cen akcji czy też kryzysu.

Tabela 11 prezentuje sumy dofinansowań i sumy budżetów wszystkich filmów fabularnych dofinansowanych przez PISF. Pozwala to na szacunkowe wyliczenie wartości rynku produkcji filmowej w Polsce $\mathrm{w}$ badanym okresie.

Tabela 11. Budżety filmów dofinansowanych przez PISF i udział PISF w produkcji [PLN] w latach 2007-2011

\begin{tabular}{lcc}
\hline Rok & Suma budżetów filmowych & Udział PISF w dofinansowanych filmach \\
\hline 2007 & 96978181,71 & 32174281,14 \\
2008 & 116488287,03 & 40704971,28 \\
2009 & 279470469,24 & 64888709,88 \\
2010 & 210359744,84 & 70558885,52 \\
2011 & 298775077,39 & 78415277,00 \\
Razem w latach 2007-2011 & 1002071760,21 & 286742124,82 \\
\hline
\end{tabular}

Źródło: opracowanie własne.

PISF w ciągu lat 2007-2011 przeznaczył na dotacje do filmów fabularnych sumę około $290 \mathrm{mln} \mathrm{zl}, \mathrm{z}$ czego około $36 \mathrm{mln}$ wydano na koprodukcje mniejszościowe - filmy zagraniczne. Sytuacja ta pokazuje, jak istotne są źródła finansowania Instytutu, powiązane ściśle z rynkiem. Gdyby pieniądze na kinematografię przeznaczane były z budżetu państwa, jedna decyzja parlamentu mogłaby w sposób drastyczny zmienić sytuację kinematografii, tak jak stało się to kilka lat temu na Węgrzech. 
Wyniki te oznaczają, że producenci powinni wykazywać większą aktywność w pozyskiwaniu alternatywnych źródeł finansowania, kształcić się w tych dziedzinach, cechować się otwartością, która często charakteryzuje producentów niezależnych (z zachowaniem proporcji, bo jak wiadomo, filmy offowe mają bardzo skromne budżety). Mimo braku sprzyjających rozwiązań prawnych, na pewno warto rozwinąć aktywność w poszukiwaniu sponsorów, rzeczowego lub finansowego product placement, zwłaszcza w przypadku filmów o niskich budżetach. Jest to jednak etap, który wymaga wielkiego zaangażowania osobistego producenta, a także wielu miesięcy poszukiwań, na co również trzeba mieć środki.

Wydaje się, że można sumę ponad 1 mld zł na rok w ciągu 5 lat uznać za pierwszą przymiarkę do oszacowania wartości rynku. Jej podstawową wadą jest brak w niej budżetów filmów powstałych bez udziału PISF. W pewnym sensie "rekompensuje” to włączenie do niej koprodukcji mniejszościowych, których budżety w dużym stopniu finansowane są przez przemysły filmowe innych krajów.

W celu właściwego oszacowania wartości rynku powinno się włączyć do niego także efekty dystrybucyjne. Dobrze opisane i policzone są jedynie wpływy z wyświetlania polskich filmów w kinach i te dane przytaczam oraz interpretuję. Film jednak żyje na wielu polach eksploatacji - w telewizji, na płytach DVD lub poprzez platformy VOD. Producent ma obowiązek stopniowego i proporcjonalnego zwrotu do PISF dotacji, jeśli film pokrył koszty produkcji, jednakże moment ten wydaje się przedwczesny, filmy te nadal uważane są za nowe i nadal intensywnie dystrybuowane.

Niezwykle ciężko jest oszacować zwrot z wielu pól eksploatacji, tym bardziej że jest to proces wielokierunkowy, przejawiający się i we wpływach z udziału reklamodawców i przychodach stacji, i w wielu innych czynnikach. Wydaje się, że takie badanie jest możliwe, musiałoby być ono jednak przeprowadzane przez co najmniej kilkuosobowy interdyscyplinarny zespół, wykorzystujący różne metody badawcze. Uzyskanie tych informacji wymagałoby zorganizowanej, prowadzonej pod kuratelą PISF i MKiDN, akcji lobbystycznej i informacyjnej, negocjacji z producentami, nadawcami i operatorami usług audiowizualnych. Umowy o współpracy między telewizjami a Instytutem na pewno mogłyby ułatwić podnoszenie stanu naszej wiedzy na ten temat, jednakże należałoby dobrze przygotować narzędzia badawcze.

Wreszcie, niemożliwy do oszacowania jest ogromny rynek piractwa internetowego, z którego zapewne część (ale jaka?) to kwota odjęta od budżetu polskiego przemysłu filmowego. Wielką wartość przede wszystkim praktyczną - miałoby oszacowanie potencjalnych zysków płynących ze zmian prawa finansowego i podatkowego, czyli wykazanie, ile polskie państwo i polska kinematografia zyskałaby dzięki wprowadzeniu rozwiązań takich jak zwrot VAT czy ulgi inwestycyjne albo system kredytów i gwarancji dostosowanych do realiów przemysłów kreatywnych. 
Z drugiej jednak strony pojawiła się okazja, by opisać i przeanalizować sytuację kinematografii w stanie dynamicznego rozwoju rynkowego, kiedy liczba danych jest ograniczona. Dla przyszłych badaczy będzie to dokumentacja obrazująca stan kinematografii u progu dalszego rozwoju, a także solidne podłoże faktograficzne i punkt wyjścia, od którego można będzie budować kolejne analizy i wnioski. 